Jurnal Akuntansi \& Perpajakan, Volume 3, No. 1, Januari 2021

\title{
PERLAKUAN AKUNTANSI ATAS SELISIH KURS DALAM TRANSAKSI MATA UANG ASING TERHADAP LABA BERSIH PADA PT. DIANTA MITRAFAIRINDO INTERNASIONAL
}

\author{
Saprudin ${ }^{1}$, Qurotul Aini ${ }^{2}$, Arie Marthin Parulian Napitupulu ${ }^{3}$ \\ Sekolah Tinggi Ilmu Ekonomi Jayakarta ${ }^{1,2,3}$ \\ saprudinmaksudi@gmail.com¹, qurotulaini663@gmail.com², \\ ariemp_napitupulu@stie.jayakarta.ac.id ${ }^{3}$
}

\begin{abstract}
ABSTRAK
Transaksi mata uang asing yang terjadi pada PT. Dianta Mitrafairindo Internasional ini terjadi karena adanya penagihan, pembayaran, atau penggantian yang ditujukan langsung pada kantor pusat Messe Frankfurt, Jerman atau pun klien yang berada diluar Indonesia, sehingga dalam melakukan transaksinya perlu menggunakan nilai tukar, dikarenakan mata uang antar negara yang berbeda. Teknik yang digunakan dalam penelitian ini, menggunakan metode kualitatif dengan pendekatan deskriptif, yaitu untuk menggambarkan objek penelitian berdasarkan fakta-fakta yang tampak atau sebagai mana adanya. Dalam transaksi penerimaan dan pengeluaran dengan negara yang berbeda, maka menggunakan 2 (dua) mata uang yaitu mata uang asing dan mata uang lokal. Dalam hal transaksi dengan mata uang yang berbeda maka akan menghasilkan keuntungan dan kerugian yang disebabkan kurs nilai tukar antara dua mata uang tersebut. Hasil penelitian menunjukkan Selisih niali tukar yang timbul saat penyelesaian pos moneter, karena kurs yang berbeda antara pada saat pos moneter tersebut dijabarkan pada pengakuan awal selama periode atau pada saat realisasi atau akhir periode, diakui dalam laba atau rugi dalam periode pada saat terjadi. Untuk perlakuan selisih kursnya PT Dianta Mitrafairindo Internasional menerapkan sesuai peraturan pemerintah (PP) 23/2018, dan dalam perhitungan biaya penghasilan pajak menggunakan PP 46/Final sehingga dalam pembuatan laporan keuangannya tidak adanya koreksi fiskal. Kebijakan akuntansi dalam laporan keuangan PT. Dianta Mitrafairindo Internasional atas transaksi mata uang asing : (1) Pengakuan penghasilan dan biaya menggunakan kurs pada tanggal pencatatan, (2) Realisasi penerimaan dan pembayaran menggunakan kurs pada tanggal transaksi, (3) Penyesuaian saldo pos moneter akhir periode laporan (akhir bulan).
\end{abstract}

Kata Kunci: Perlakuan Akuntansi, Mata Uang Asing, Laporan Keuangan, Laba bersih

\section{PENDAhUluan}

Berkembangnya teknologi saat ini, membuat para pengguna merasa dimudahkan dan lebih efektif dalam melakukan sesuatu. Ini menandakan adanya perkembangan zaman yang lebih baik. Kemajuan dalam teknologi ini, banyak dirasakan oleh para kalangan,individu, maupun secara kelompok. Dan dari sisi lain berkembangnya teknologi ini sangat mempengaruhi bagi pelaku usaha untuk melebarkan sayapnya ke negara lain serta memicu perusahaanperusahaan untuk menjalin kerjasama 
Jurnal Akuntansi \& Perpajakan, Volume 3, No. 1, Januari 2021

yang baik dengan pihak asing atau pihak luar. menjelaskan bahwa dalam pelaksanaan kerjasama harus tercapai keuntungan bersama (2007: 50-51), pelaksanaan kerjasama hanya dapat tercapai apabila di peroleh manfaat bersama bagi semua pihak yang terlibat didalamnya (win-win). Melakukan kerjasama bisa dilakukan oleh antar perusahaan, organisasi maupun kelompok dan tidak hanya terbatas antara satu negara dengan negara lain, tetapi dapat dilakukan lintas kawasan benua sehingga menuntut perusahaan untuk tidak hanya menjalin kerjasama dengan perusahaan domestik. Perdagangan bebas menjalin kerjasama dengan asing tidak hanya melihat pada pasar domestik, tetapi melihat pangsa pasar negara - negara lain. Perusahaan melakukan aktivitas luar negeri dalam dua cara yaitu perusahaan yang memiliki transaksi dalam mata uang asing atau memiliki kegiatan usaha diluar negeri.

Dalam transaksi perdagangan internasional umumnya menggunakan mata uang (valuta) asing. Menurut Hamdy Hadi (2010: 97) "Mata uang asing yang difungsikan sebagai alat pembayaran untuk membiayai transaksi ekonomi keuangan internasional dan juga mempunyai catatan kurs resmi pada bank sentral". Dalam hal perdagangan internasional atau transaksi antar entitas bisnis negara-negara yang berbeda, jumlah utang maupun piutang biasanya dilaporkan dalam mata uang lokal dari negara pembeli ataupun penjual (Hasibuan dan Nopryannus, 2013). Dengan kata lain perusahaan harus melakukan translasi yaitu penjabaran mata uang asing kedalam mata uang fungsional, atas piutang transaksi internasionalnya menjadi Rupiah. Bekerjasama dengan negara lain tentunya dalam transaksi menggunakan valuta asing, valuta asing sendiri merupakan pertukaran atau konversi mata uang suatu negara dengan negara lain. Transaksitransaksi yang berhubungan dengan mata uang asing seperti transaksi jualbeli valuta asing, pinjaman luar negeri, ekspor-impor dan jasa lain yang terkait dengan mata uang asing.

Valuta asing merupakan suatu mekanisme dimana orang dapat mentransfer daya beli antar negara, memperoleh atau menyediakan kredit untuk transaksi perdagangan internasional, dan meminimalkan resiko kerugian akibat terjadinya fluktuasi kurs suatu mata uang, dikarenakan perbedaan nilai mata uang tiap Negara.

Bagi negara berkembang seperti Indonesia, peranan kurs valuta asing menjadi sangat penting. Dikarenakan sebagai negara yang tengah melakukan pembangunan ekonomi, maka kurs valuta asing akan berhubungan langsung dengan sektorsektor perdagangan luar negeri, investasi, bahkan berkaitan langsung dengan beban hutang kuar negeri yang merupakan sumber dana pembangunan.

Dalam hal bertransaksi menggunakan valuta asing tentunya 
Jurnal Akuntansi \& Perpajakan, Volume 3, No. 1, Januari 2021

ada selisih kurs sehingga dapat menimbulkan kerugian ataupun keuntungan atas selisih tersebut. Laba atau rugi ini adalah perbedaan yang terjadi antara kurs pada tanggal terjadinya transaksi kontrak kerja atau pada saaat realisasi pembayaran. Permasalahan lain dalam melakukan transaksi luar negeri adalah kurs mana yang akan di gunakan dan bagaimana melaporkan pengaruh dari perubahan kurs dalam laporan keuangan. Di samping itu, kondisi lingkungan ekonomi, tuntutan akuntabilitas dan transparan dalam laporan keuangan, serta pemangku kepentingan (stakeholders) adalah beberapa faktor adanya peraturan atau standar dalam menjalankan aktivitas perusahaan termasuk aktivitas luar negeri.

Atas perlakuan akuntansi transaksi dalam mata uang asing cukup mempengaruhi laporan keuangan yaitu pada akun pendapatan hutang, piutang dan lainnya. Perlakuan akuntansi terhadap laba/rugi selisih kurs yang terjadi dari mata uang asing ada tiga, yaitu: (1) diakui sebagai pendapatan (biaya) pada periode tahun berjalan. dikapitalis sebagian, dan (3) dikapitalisasi penuh. Tiga metode pengakuan laba-rugi selisih kurs ini perlu dikaji secara mendalam dikarenakan masing-masing metode menimbulkan persepsi yang berbedabeda. Diantaranya, metode pertama dianggap tidak menimbulkan konsekuensi ekonomi, sedangkan dua metode lainnya dianggap sebaliknya. Perlakuan akuntansi yang
dilakukan harus sesuai dengan ketentuan yang berlaku secara umum yaitu perlakuan akuntansi yang mengacu pada Standar Akuntansi Keuangan (SAK) agar dapat dipergunakan oleh pihak-pihak yang berkepentingan sebagai bahan pertimbangan dalam pengambilan keputusan.

Dalam hal perlakuan akuntansi selisih kurs ini yang digunakan sebagai acuan adalah pernyataan Standar Akuntansi Keuangan (PSAK) N0.10 tentang transaksi dalam mata uang asing, namun tidak semua perusahaan mengikuti ketentuan perlakuan akuntansi dalam transaksi mata uang asing yang berlaku secara umum. Apabilan laporan keuangan atas mata uang asing masih digunakan tanpa penjelasan atas perubahan nilai dalam kondisi inflasi, maka akan mengakibatkan laporan keuangan yang sudah tidak relevan lagi bagi pengguna laporan keuangan.

PT. Dianta Mitrafairindo Internasional sendiri merupakan perwakilan resmi Messe Frankfurt Exhibition $\quad \mathrm{GmbH}, \quad$ yaitu penyelenggara pameran perdagangan yang berputasi Internasional yang berkantor pusat di Frankfurt, Jerman. Oleh karena itu hubungan bisnis yang terjadi antar Negara maka bentuk penerimaan serta pembayaran dalam mata uang asing. Maka penulis ingin meneliti apakah ada pengaruhnya laba bersih setelah pajak serta perlakuan akuntansinya atas dasar transaksitransaksi selisih kurs yang terjadi.

\section{LITERATUR}


Jurnal Akuntansi \& Perpajakan, Volume 3, No. 1, Januari 2021

Terdapat dua Kepentingan yang berbeda didalam perusahaan dimana masing-masing pihak berusaha untuk mencapai kemakmuran yang dikehendaki, sehingga munculah informasi asimetri antara manajemen dengan pemilik yang dapat memberikan kesempatan kepada manajer untuk melakukan manajemen laba dalam rangka menyesatkan pemilik mengenai kinerja ekonomi perusahaan (Sefiana, 2009)

Masalah keagenan (agency problem) pada awalnya dieksplorasi oleh Ross (1973), sedangkan eksplorasi teoritas secara mendetail dari teori keagenan pertama kali dinyatakan oleh Jensen and Mecking (1976) menyebutkan manajer suatu perusahaan sebagai “ agen" dan pemegang saham " Principal”.

Terdapat cara-cara langsung yang digunakan pemegang saham untuk memonitor manajemen perusahaan sehingga membantu memecahkan konflik keagenan. Pertama, pemegang saham mempunyai hak untuk mempengaruhi cara perusahaan dijalankan melalui voting dalam rapat umum pemegang saham, hak voting pemegang saham merupakan bagian penting dari aset keuangan mereka. Kedua pemegang saham melakukan resolusi di mana suatu kelompok pemegang saham secara kolektif melakukan lobby terhadap manager (mewakili perusahaan) berkenan dengan isu-isu yang tidak memuaskan mereka. Pemegang saham juga mempunyai opsi divestasi (menjual saham mereka) divestasi mereprestasikan suatu kegagalan dari perusahaan untuk mempertahankan investor, di mana divestasi diakibatkan oleh ketidakpuasan pemegang saham atas aktivitas manajer (Warsono, 2009).

Menurut Baridwan Zaki (2004: 17-18), laporan keuangan merupakan ringkasan dari suatu proses pencatatan yang berisi suatu ringkasan dari transaksi-transaksi keuangan yang terjadi selama tahun buku yang bersangkutan laporan keuangan ini dibuat oleh manajemen dengan tujuan untuk mempertanggungjawabkan tugastugasnya yang dibebankan kepadanya oleh para pemilik perusahaan.

Adapun Hery (2015: 3), menjelaskan Laporan keuangan (financial statements) merupakan proses pencatatan dan pengikhtisaran data transaksi bisnis yang digunakan sebagai alat untuk mengkomunikasikan data keuangan atau aktivitas perusahaan kepada pihak-pihak yang berkepentingan. Dan Kasmir (2013: 7) menyatakan Laporan keuangan adalah laporan yang menunjukkan kondisi keuanangan perusahaan saat ini atau periode kedepannya. Maksud dan tujuan laporan keuangan menunjukkan kondisi keuangan perusahaan.

Menurut Ikatan Akuntan Indonesia (IAI) (2007: 7), mengemukakan bahwa: "Laporan keuangan merupakan bagian dari proses pelaporan keuangan. Laporan keuangan yang lengkap biasanya 
Jurnal Akuntansi \& Perpajakan, Volume 3, No. 1, Januari 2021

meliputi neraca, laporan laba rugi, laporan perubahan posisi keuangan (yang disajikan dalam berbagai cara misalnya laporan arus kas, atau laporan arus dana), catatan dan laporan lain serta materi penjelasan yang merupakan bagian integral dari laporan keuangan."

Jadi kesimpulannya laporan keuangan adalah Laporan yang menggambarkan dan menunjukkan kondisi keuangan suatu perusahaan, dan disusun sebagai pertanggungjawaban manajemen terhadap pihak-pihak yang berkepentingan dengan kinerja perusahaan yang dicapai selama periode tertentu. Pengguna laporan keuangan menurut Kasmir (2008:19) adalah pemilik, manajemen, kreditor, investor dan pemerintah.

Pengertian laba secara umum adalah selisih dari pendapatan di atas biaya-biayanya dalam jangka waktu (periode) tertentu. Laba sering digunakan sebagai suatu dasar untuk pengenaan pajak, kebijakan deviden, pedoman investasi serta pengambilan keputusan dan unsur prediksi (Harnanto, 2003: 444).

Besar kecilnya laba sebagai pengukur kenaikan sangat bergantung pada ketetapan pengukuran pendapatan dan biaya (Harahap, 2008: 113).

Menurut Reeve, Warren dkk (2005: 3) Laba (profit) atau keuntungan merupakan selisih antara uang yang diterima dari pelanggan atas barang atau jasa yang dihasilkan dan biaya yang dikeluarkan untuk input yang digunakan guna menghasilkan barang dan jasa.

Menurut Stice, Skousen (2009: 240), Laba adalah pengambilan atas investasi kepada pemilik. Hal ini mengukur nilai yang dapat diberikan oleh entitas kepada investor dan entitas masih memiliki kekayaan yang sama dengan posisi awalnya.

Berdasarkan beberapa definisi diatas, dapat disimpulkan bahwa laba merupakan kinerja perusahaan yang diukur dari pengurangan antara pendapatan dan beban - beban perusahaan yang terjadi pada suatu periode tertentu.

Kurs atau nilai tukar adalah suatu nilai yang menunjukkan jumlah nilai mata uang dalam negeri yang diperlukan untuk mendapatkan satu unit mata uang asing. (Sadono Sukirno, 2014: 15).

Menurut Nopirin (2012: 163) nilai tukar adalah "Harga didalam pertukaran dua macam mata uang yang berbeda, akan terdapat perbandingan nilai atau harga antara kedua mata uang tertentu, perbandingan nilai inilah yang disebut exchange rate"

Menurut Mahyus Ekananda (2014: 168) adalah "Kurs merupakan harga suatu mata uang relative terhadap mata uang negara lain. Kurs memainkan peranan penting dalam keputusan - keputusan pemebelanjaan, karena kurs memungkinkan kita menerjemahkan harga-harga dari berbagai negara ke dalam satu bahasa yang sama".

Sedangkan selisih kurs, menurut PSAK No.10 Tahun 2010 
Jurnal Akuntansi \& Perpajakan, Volume 3, No. 1, Januari 2021

adalah selisih yang dihasilkan dari penjabaran sejumlah tertentu satu mata uang ke dalam mata uang lain pada kurs yang berbeda.

Menurut Beams (2000: 468)

Mata uang fungsional dari suatu entitas adalah mata uang yang berlaku di wilayah operasi utama perusahaan. Mata uang fungsional dari sebuah entitas luar negeri adalah mata uang dengan mana perusahaan tersebut menghasilkan serta membelanjakan uang kas mereka. Jika mata uang tidak diidentifikasi dan arus kas maka faktor-faktor lain dapat dipertimbangkan.

Menurut Choi \& Meek (2005: 247) mata uang fungsional sebuah perusahaan diartikan sebagai mata uang lingkungan ekonomi yang utama dimana perusahaan beroperasi dan menghasilkan arus kas.

Menurut Jusuf (2000: 471), kurs yang digunakan dalam akuntansi untuk kegiatan dan transaksi luar negeri (selain kontrak kurs berjangka) adalah kurs spot, kurs sekarang, dan kurs historis.

PSAK Nomor 10 Tahun 2010 mempunyai ketentuan yaitu pada pengakuan awal transaksi perusahaan atau entitas:

a. Membeli atau menjual barang atau jasa yang harga didenominasikan dalam suatu mata uang asing.

b. Meminjam atau meminjamkan dana ketika jumlah yang merupakan utang atau tagihan didenominasikan dalam suatu mata uang asing, atau c. Memperoleh atau melepas aset, atau mengadakan atau menyelesaikan kewajiban yang didominasikan dalam suatu mata uang asing.

Dalam penelitian Rizki Eka Putra (2018) yang meneliti tentang Analisis Perlakuan AKuntansi Atas Selisih Kurs Dan Transaksi Dalam Mata Uang Asing Serta Pengaruhnya Terhadap Laporan Keuangan (Studi Kasus Pada PT. Appipa Indonesia). Hasil yang diperoleh dari penelitian ini adalah transaksi dalam mata uang asing dan selisih kurs yang terjadi tidak akan berpengaruh secara signifikan terhadap laporan keuangan karena transaksi tersebut dicatat pada akun tersendiri sehingga berapapun nilainya akan memberikan informasi yang terpisah pada pengguna laporan keuangan.

Perlakuan transaksi dalam mata uang asing pada PT. Appipa Indonesia yang sebagian besar dalam mata uang US Dollar sedangkan, mata uang pelaporan yang digunakan adalah mata uang rupiah telah berdasarkan pada PSAK N0.10.

\section{III.METODE}

Ditinjau dari permasalahan dalam penelitian, penelitian ini menggunakan metode kualitatfif dengan pendekatan deskriptif. Penelitian deskriptif kualitatif adalah penelitian yang menggambarkan atau melukiskan objek penelitian berdasarkan fakta-fakta yang tampak atau sebagai mana adanya. Nawawi dan Martini (1996: 73). 
Jurnal Akuntansi \& Perpajakan, Volume 3, No. 1, Januari 2021

Metode kualitatif dengan pendekatan studi deskriptif analitik yang dipakai dalam penelitian ini, sebgaimana yang di ungkapkan oleh Sugiyono, (2012: 3) adalah metode kualitatif untuk mendapatkan data yang mendalam, suatu data yang mengandung makna. Metode kualitatif secara siginifkan dapat mempengaruhi substansi penelitian. Artinya bahwa metode kualitatif menyajikan secara langsung hakikat hubungan antar peneliti dan informan, objek dana subjek penelitian.

Penelitian kualitatif datanya diperoleh dari berbagai sumber dengan menggunakan teknik pengumpulan data yang bermacammacam (iriangulasi) dan dilakukan secara terus-menerus sampai datanya lengkap (Fatihudin 2014: 148). Pengamatan yang terus-menerus tersebut mengakibatkan variasi data menjadi tinggi umumnya data yang diperoleh bersifat kualitatif sehingga teknik analisis data yang digunakan belum ada polanya yang jelas oleh karena itu peneliti sering mengalami kesulitan untuk melakukan analisisnya.

Variabel independen dalam penelitian ini adalah kurs atau nilai tukar. Kurs atau nilai tukar adalah suatu nilai yang menunjukkan jumlah nilai mata uang dalam negeri yang diperlukan untuk mendapatkan satu unit mata uang asing.(Sadono Sukirno, 2014: 15). Adapun variabel dependen dalam penelitian ini adalah Laba bersih. Menurut Zaki (2004: 65) Laba bersih merupakan ukuran beberapa besar harta yang masuk (pendapatan dan keuntungan) melebihi harta yang keluar (beban dan kerugian) suatu usaha.

Teknik yang digunakan peneliti dalam mengumpulkan data, yaitu melalui kajian pustaka dan studi lapangan yang dilakukan melalui wawancara dengan manajemen (interview) dan pengamatan langsung terhadpa objek peneltian (Observation).

Populasi dalam penelitian ini adalah PT. Dianta Mitrafairindo Internasional, adapun sampel yang digunakan dalam penelitian ini adalah laporan keuangan Tahun 2018-2019.

Teknik analisis data yang digunakan dalam penelitian ini adalah deskriptif, dengan lebih banyak bersifat uraian dari hasil wawancara dan studi dokumentasi. Data yang telah diperoleh akan di analisis secara kualitatif serta diuraikan dalam bentuk deskriptif.

Menurut Patton Moleong (2001: 103), analisis data adalaah proses mengatur urutan data, mengorganisasikannya ke dalam suatu pola, kategori dan uraian dasar. Sedangkan menurut Sugiyono (2013:244) analisis data adalah proses mencari dan menyusun secara sistematis data yang diperoleh dari hasil dokumentasi observasi dan bahan-bahan lain, sehingga dapat mudah dipahami dan temuannya dapat diinformasikan kepada orang lain.

Peneliti mengolah data penelitian yang diambil melalui teknik pengumpulan data, kemudian 
Jurnal Akuntansi \& Perpajakan, Volume 3, No. 1, Januari 2021

menganalisis data yang didapat dari dokumentasi dan observasi, serta membandingkan dengan teori-teori yang diperoleh dan literatur. Peneliti akan membandingkan pencatatan dan pengaruh selisih kurs pada laporan keuangan PT. Dianta Mitrafairindo Internasional, Jakarta.

Dengan pencatatan dan pengaruh selisih kurs yang sesuai dengan PSAK Nomor 10 tujuannya adalah untuk melihat dan membandingkan

kesesuaian pencatatan dan pengaruh selisih kurs pada PT.Dianta Mitrafairindo Internasional terhadap ketentuan standar akuntansi yang berlaku.

\section{IV.HASIL DAN PEMBAHASAN}

PT. Dianta Mitrafairindo Internasional didirikan pada bulan April 2010 sebagai mitra penjualan resmi PT. Pameran Messe Frankfurt di Indonesia. PT Dianta Mitrafairindo Internasional didirikan oleh Ibu Dian Indrianty (Direktur) dan Ibu Yunita Wulan Andadari (Wakil Direktur), PT Dianta Mitrafairindo Internasional sendiri, sebagai perwakilan resmi salah satu penyelanggara pameran dagang terbesar di Dunia, yaitu Messe Frankfurt $\mathrm{GmbH}$, penyelenggara pameran perdagangan yang bereputasi Internasional yang berkantor pusat di Frankfurt,Jerman. Dimana bertugas atau berperan memandu para pengusaha-pengusaha kecil menengah sampai perusahaan besar untuk memasarkan produkproduk yang dihasilkan, yang diapasarkan di pasar global melalui berbagai pameran perdagangan di Jerman, Prancis, Hong Kong, Jepang, Cina, Uni Emirat Arab, dan banyak negara lainnya.

Adapun beberapa bisnis yang dipamerkan, seperti : furniture dan aksesoris rumah, kertas dan alat tulis,perawatan kecantikan dan rambut, produk dan teknologi tekstil hingga suku cadang dan komponen otomotif yang akan dipertemukan dengan industri diberbagai negara.

Berdasarkan data penelitian yang berasal dari laporan keuangan PT. Dianta Mitrafairindo Internasional yang diperoleh langsung dari Staff Accounting. Dalam penelitian ini yang menjadi objek adalah laporan keuangan perusahaan yang telah menjadi sampel kemudian di analisis dan dicari nilai laba bersih dan selisih kurs yang tertera pada laporan keuangan Tahun 2018 dan 2019. Transaksi dalam mata uang asing pada PT Dianta Mitrafairindo Internasional terjadi adanya tagihantagihan (invoice) maupun debit note (DBN) yang diterima atau ditujukan langsung kepada klien ataupun kepada Messe Frankfurt Exhibiton $\mathrm{GmbH}$ Jerman, dimana dalam transaksinya menggunakan kurs, dikarenakan mata uang yang berbeda Indonesia dengan negara lainnya. Dari transaksi tersebut timbul adanya selish kurs, dan menyebabkan adanya kerugian atau keuntungan selisih 
Jurnal Akuntansi \& Perpajakan, Volume 3, No. 1, Januari 2021

Laporan Laba Rugi PT. Dianta Mitrafairindo Internasional Tahun 2018-2019 PT. DIANTA MITRAFAIRINDO INTERNASIONAL Laporan Laba Rugi Untuk Periode yang berakhir pada 31 Desember 2019 dan 2018 (dalam Rupiah / IDR)

\begin{tabular}{|c|c|c|}
\hline & \multirow[b]{2}{*}{$\begin{array}{l}\text { Lap. Keuangan } \\
\text { Jan - Dec } 2019\end{array}$} & \multirow[b]{2}{*}{$\begin{array}{l}\text { Lap. Keuangan } \\
\text { Jan - Dec } 2018\end{array}$} \\
\hline & & \\
\hline PENGHASILAN USAHA & 2.209 .289 .273 & 2.150 .363 .843 \\
\hline \multicolumn{3}{|l|}{ BIAYA OPERASIONAL } \\
\hline Gaji dan Tunjangan & $(911.106 .509)$ & $(852.509 .671)$ \\
\hline PengembanganSDM & $(8.200 .000)$ & $(8.200 .000)$ \\
\hline Sewa Ruang Kantor \& Peralatan & $(89.184 .000)$ & $(108.686 .800)$ \\
\hline Perlengkapan Kantor & $(38.394 .842)$ & $(38.606 .700)$ \\
\hline Biaya Perbaikan Perlengkapan Kantor & $(1.150 .000)$ & $(575.000)$ \\
\hline Perjalanan Dinas & $(85.666 .210)$ & $(68.733 .632)$ \\
\hline Telekomunikasi & $(33.483 .765)$ & $(53.508 .643)$ \\
\hline Konsultasi & $(112.484 .500)$ & $(142.251 .456)$ \\
\hline Biaya Rapat dan Jamuan & $(7.055 .350)$ & $(4.962 .700)$ \\
\hline Biaya Iklan & $(14.000 .000)$ & - \\
\hline Biaya Event Organizer & $(68.204 .618)$ & $(50.311 .250)$ \\
\hline Biaya Penyusutan & $(26.905 .864)$ & $(30.560 .913)$ \\
\hline Biaya Administrasi Bank & $(3.678 .911)$ & $(3.747 .781)$ \\
\hline JUMLAH BEBAN USAHA & $(1.399 .514 .569)$ & $(1.362 .654 .546)$ \\
\hline LABA / (RUGI) USAHA & 809.774 .704 & 787.709 .297 \\
\hline \multicolumn{3}{|l|}{ Pendapatan dan Biaya lain-lain } \\
\hline Penghasilan Bunga Bank (net) & 40.412 .935 & 36.946 .654 \\
\hline Penghasilan Lain-lain & 7.087 .002 & 11.000 .000 \\
\hline Laba (Rugi) Selisih Kurs & $(81.649 .195)$ & 4.418 .644 \\
\hline Biaya Zakat & $(82.501 .167)$ & $(46.956 .500)$ \\
\hline JUMLAH HASIL (BEBAN) LAIN-LAIN & $(116.650 .425)$ & 5.408 .798 \\
\hline LABA / (RUGI) SEBELUM PAJAK & 693.124 .279 & 793.118 .095 \\
\hline Biaya Pajak Penghasilan (PP 46/Final) & (11.046.445) & (16.279.108) \\
\hline LABA / (RUGI) SETELAH PAJAK & 682.077 .834 & 776.838 .987 \\
\hline
\end{tabular}

\section{Penentuan Penggunaan Kurs}

Pencatatan Transaksi harian dalam mata uang asing dijabarkan ke mata uang rupiah dengan menggunakan kurs yang berlaku pada tanggal transaksi dengan menggunakan kurs Menteri
Keuangan untuk menghindari selisih kurs mata uang asing yang signifikan antara laporan keuangan dan kewajiban perpajakan yang harus disetor, dalam hal ini PPh Pasal 4 (2) sesuai PP 23/2018. Saldo akun moneter pada akhir periode 
Jurnal Akuntansi \& Perpajakan, Volume 3, No. 1, Januari 2021

pelaporan (31 Desember 2018 dan 2019) menggunakan kurs BI.

Keuntungan dan kerugian dari selisih kurs yang timbul dari transaksi dalam mata uang asing dan penjabaran aset dan kewajiban moneter dalam mata uang asing diakui pada laporan laba rugi tahun yang bersangkutan.

\section{Laporan Keuangan PT. Dianta Mitrafairindo Internasional}

Laporan keuangan merupakan suatu bentuk output dari hasil akhir proses akuntansi yang menjadi salah satu bahan dalam proses pengambilan keputusan. Oleh karena itu, laporan keuangan harus disusun secara benar sesuai standar yang ada dengan siklus akuntansi yang benar. Dalam pencatatan dan penyajian laporan keuangan yang dilakukakan PT. Dianta Mitrafairindo Internasional dari hasil analisis, bahwa PT. Dianta Mitrafairindo Internasional sejak tahun pendirian sampai dengan sekarang adalah mata uang Rupiah. Laporan keuangan yang telah disusun sudah sesuai dengan prinsip dan praktek akuntansi yang berlaku umum di Indonesia, yaitu Pernyataan Standar Akuntansi Keuangan (PSAK) 10. Dimana diantaranya:

1) Pos moneter mata uang asing dijabarkan menggunakan kurs penutup

2) Pos non moneter (Aset tetap) dalam mata uang asing dijabarkan menggunakan kurs pada tanggal transaksi (historical value)

3) Aset Tetap dapat ditentukan berdasarkan biaya historis.

Selain itu laporan keuangan disusun dengan dasar akrual (accrual basis). Dalam PSAK No.1 disebutkan bahwa laporan keuangan yang lengkap terdiri dari Neraca, Laporan Laba Rugi, Laporan Perubahan Modal dan Laporan Arus Kas.

\section{Pengakuan atau Perlakuan Akuntansi atas Selisih Kurs}

Perlakuan akuntansi yang diharuskan sehubungan dengan selisih kurs atas transaksi dalam mata uang asing mencakup perlakuan wajib (benchmark treatment). Selisih kurs timbul apabila terdapat perubahan kurs antara tanggal transaksi pembelian dan tanggal penyelesaian atau pembayaran (settlement date) yang timbul dari transaksi pembelian yang dicatat ke dalam mata uang asing. Bila timbulnya dan penyelesaian suatu transaksi pembelian berada dalam suatu periode akuntansi yang sama, maka seluruh selisih kurs diakui dalam periode tersebut. Namun jika timbulnya dan diselesaikan atau pembayaran suatu transaksi pembelian berada dalam beberapa periode akuntansi dengan memperhitungkan perubahan kurs untuk setiap masing - masing periode. 
Jurnal Akuntansi \& Perpajakan, Volume 3, No. 1, Januari 2021

Dari hasil wawancara yang dilakukan dengan manajemen terkait laporan keuangan untuk perlakuan selisih kurs pada PT. Dianta Mitrafairindo Internasional atas transaksi penerimaan dan pengeluaran kas atau bank diakui saat terjadinya transaksi dan langsung dicatat sebagai laba atau rugi kurs dalam laporan laba rugi.

Dari laporan keuangan diatas, terlihat bahwa pada tahun 2018 dalam selisih kurs mengalami kerugian sebesar Rp.81.649.195 sedangkan pada tahun 2019 mendapatkan keuntungan (laba) selisih kurs sebesar Rp.4.418.644. Dalam hal ini PT Dianta Mitrafairindo Internasional dalam perhitungan biaya pajak penghasilan menggunakan PP 46/Final sehingga berpengaruh langsung terhadap laba bersih setelah pajak, dapat dilihat pada tabel 2 .

Hal ini dalam penelusuran peniliti, selisih nilai tukar yang timbul saat penyelesaian pos moneter, karena kurs yang berbeda antara pada saat pos moneter tersebut dijabarkan pada pengakuan awal selama periode atau pada periode laporan keuangan sebelumnya dengan kurs pada saat realisasi atau akhir periode, diakui dalam laba atau rugi dalam periode pada saat terjadinya. Oleh sebab itu, Hal-hal yang menyebabkan laba atau rugi dari selisih kurs yang terjadi pada PT. Dianta Mitrafairindo Internasional adalah: a) Transaksi transfer dari EUR ke IDR, karena saat transaksi bank akan menggunakan kurs pada hari itu sedangkan dalam pencatan menggunakan kurs Menteri Keuangan

b) Transaksi realisasi penerimaan piutang usaha dan pembayaran hutang usaha dalam mata uang asing

c) Penyesuai saldo pos moneter akhir periode laporan (akhir bulan).

Dalam perlakuan selisih kurs PT. Dianta Mitrafairindo menerapkan sesuai Peraturan Pemerintah (PP) 23/2018 tentang pajak penghasilan atas penghasilan dari usaha yang diterima atau diperoleh wajib pajak yang memiliki peredaran bruto tertentu. Artinya dalam pembuatan laporan keuangan tidak adanya koreksi fiskal. Namun apabila perlakuan selisih kurs tidak menggunakan PP 23 maka selisih kurs yang tercatat dalam laporan keuangan laba rugi akan menjadi salah satu faktor penambah atau pengurang dalam laporan laba rugi menurut fiskal dan akan mempengaruhi besar kecilnya pajak penghasilan yang terutang. Selisih kurs yang diakui secara perpajakan adalah selisih kurs atas transaksi yang telah terealisasikan.

\section{Kebijakan Akuntansi}

Kebijakan akuntansi dalam laporan keuangan PT Dianta Mitrafairindo Internasional atas transaksi dalam mata uang asing : 
Jurnal Akuntansi \& Perpajakan, Volume 3, No. 1, Januari 2021

1) Pengakuan penghasilan dan biaya menggunakan kurs pada tanggal pencatatan

2) Realisasi penerimaan dan pembayaran menggunakan kurs pada tanggal transaksi

3) Penyesuaian saldo pos moneter akhir periode laporan (akhir bulan)

Perusahaan tidak menerapkan Hedging atau lindung nilai atas transaksi menggunakan mata uang asing. Dalam pencatatan hariannya manajemen PT. Dianta Mitrafairindo Internasional menggunakan kurs Menteri Keuangan untuk mempermudah rekonsiliasi antara peghasilan dan pajak penghasilan yang di setor berdasarkan PP 23/2018 dan antara biaya dan pemotongan PP Pasal 21 / 23 / 26, tetapi pada akhir periode (31 Desember 2018 dan 2019) menggunakan kurs tengah BI.

\section{KESIMPULAN}

Berdasarkan hasil pengolahan data dan analisis yang telah dilakukan oleh peneliti maka dapat disimpulkan bahwa dalam penggunaan kurs mata uang asing PT. Dianta Mitrafiairndo Internasional transaksi harian persuahaan dalam mata uang asing telah dijabarkan ke mata uang rupiah dengan menggunakan kurs yang berlaku pada tanggal transaksi yaitu dengan menggunakan kurs Menteri Keuangan. Hal ini untuk menghindari selisih kurs mata uang asing yang signifikan antara laporan keuangan dan kewajiban perpajakan yang harus di setor, saldo akun moneter pada akhir periode pelaporan (31 Desember 2018 dan 2019) menggunakan kurs BI.

Hal - hal yang menyebabkan laba atau rugi dari selisih kurs yang terjadi pada PT. Dianta Mitrafiairindo Internasional adalah :

a) Transaksi transfer dari EUR ke IDR, karena saat bank akan menggunakan kurs pada hari itu sedangkan dalam pencatatan menggunakan kurs Menteri Keuangan.

b) Transaksi realisasi penerimaan piutang usaha dan pembayaran hutang usaha dalam mata uang asing

c) Penyesuaian saldo pos moneter akhir periode laporan (akhir bulan).

Perlakuan selisih kurs pada PT. Dianta Mitrafairindo Internasional terkait dengan ketentuan perpajakan, perusahaan menerapkan sesuai Peraturan Pemerintah PP 23/2018, dan dalalam perhitungan biaya penghasilan pajak menggunakan PP 46/Final sehingga dalam pembuatan laporan keuangan tidak adanya koreksi fiskal. Namun apabila perlakuan selisih kurs tidak menggunakan PP 23 maka selisih kurs yang tercatat dalam laporan keuangan laba rugi akan menjadi salah satu penambah atau pengurang dalam laporan laba rugi menurut fiskal dan akan mempengaruhi besar kecilnya pajak penghasilan yang terutang. Selisih kurs yang diakui secara perpajakan adalah selisih kurs atas transaksi yang telah 
Jurnal Akuntansi \& Perpajakan, Volume 3, No. 1, Januari 2021

terealisasikan. Namun kendati itu perusahaan tidak menerapkan Hedging atau lindung nilai atas transaksi mata uang asing.

Untuk penyusunan laporan keuangan PT Dianta Mitrafairindo Internasional sudah sesuai dengan PSAK No.10 dimana :

1) Pos moneter mata uang asing dijabarkan menggunakan kurs penutup

2) Pos non moneter (Aset tetap) dalam mata uang asing dijabarkan menggunakan kurs pada tanggal transaksi (historical value)

3) Aset tetap dapat ditentukan berdasarkan biaya historis.

Kebijakan Akuntansi dalam laporan keuangan PT Dianta Mitrafairindo Internasional atas transaksi dalam mata uang asing:

1) Pengakuan penghasilan dan biaya menggunakan kurs pada tanggal pencatatan

2) Realisasi penerimaan dan pembayaran menggunakan kurs pada tanggal transaksi

3) Penyesuasi saldo pos moneter akhir periode laporan (akhir bulan).

Dengan demikian perusahaan diharapkan memperhatikan besar kecilnya selisih kurs atas transaksitransaksi yang terjadi, dan diharapkan dapat menggunakan Hedging atau lindung nilai yaitu untuk meminimalisirkan resiko, karena perubahan kurs bagi perusahaan mempunyai dampak potensial pada tingkat profitiabilitas, arus kas bersih dan nilai pasar perusahaan dan stabilitas sistem keuangan perusahaan.

\section{REFERENSI}

Baridwan, Zaki (2004), Intermediate Accounting "Pengantar Akuntansi”, Buku 2, Edisi 21, Salemba Empat. Jakarta.

Beams, Floyd A dan Amir Abadi Jusuf. 2000. Akuntansi Keuangan Lanjutan di Indonesia. Jakarta : Salemba Empat.

Bowo dan Andy (2007). Teori Kerjasama, [online] (https://lompoulu.com/?b2w=htt ps://lompoulu.blogspot.com/201 3/06/pengertian-kerjasama.html, diakses tanggal 08-03-20; pukul 21.15).

Carls S, Warren, James M. Reeve \& Philips E. Fess. 2005. Accounting. Salemba Empat; Jakarta.

Fatihudin, Didin. 2014. Metode Penelitian. Sidoarjo: Zifatama Publisher

Ekananda, Mahyus. 2014. Ekonomi Internasional. Jakarta: Erlangga.

Frederick D.S. Choi dan Gary K. Meek, Penerjemah Edaward Tanujaya, 2005, Akuntansi Internasional, Salemba Empat, Jakarta.

Hamdy Hadi. 2010. Manajemen Keuangan Internasional, Edisi ke dua, Salemba Empat, Jakarta.

Harnanto, 2003. Akuntansi Keuangan Menengah, Edisi 2003/2004, BPFE-Yogyakarta, Yogyakarta.

Hasibuan, D.H.M. dan Nopryannus. 2013. Analisis Selisih Kurs dan 
Jurnal Akuntansi \& Perpajakan, Volume 3, No. 1, Januari 2021

Pengaruhnya Terhadap

Laporan Laba Rugi

Perusahaan. Jurnal Ilmiah

Akuntansi Kesatuan (JIAKES)

Vol. 1, No. 2, pg 151-160. ISSN

2337-7852.

Hery. 2015. Analisis Laporan Keuangan. Edisi 1. Yogyakarta: Center For Academic Publishing Services.

Ikatan Akuntansi Indonesia. PSAK No. 1 Tentang Laporan Keuangan- edisi revisi 2015. Penerbit Dewan Standar Akuntansi Keuangan: PT. Raja Grafindo

Ikatan Akuntan Indonesia (IAI). 2007. Standar Akuntansi Keuangan. Jakarta: Salemba Empat.

Ikatan Akuntansi Indonesia. 2010. PSAK 10 (Revisi 2010): Pengaruh Perubahan Kurs Valuta Asing. Jakarta : IAI

Kasmir. 2013. Analisis Laporan Keuangan. Rajawali Pers : Jakarta.

Kasmir. (2008). Bank dan Lembaga Keuangan Lainnya. Jakarta: PT. Raja Grafindo Persada.

Moloeng, Lexi J. 2001. Metodologi Penelitian Kualitatif. Bandung: PT. Remaja Rosda Karya

Nawawi Hadari dan Mini Martini. 1996. Penelitian Terapan. Yogyakarta: UGM Press

Nopirin. 2012. Pengantar Ilmu Ekonomi Mikro Makro. Yogyakarta: BPFE Yogyakarta.
Putra, Eka, Rizki. 2018. Analisis Perlakuan Akuntansi atas Selisih Kurs dan Transaksi Dalam Mata Uang Asing Serta Pengaruhnya TerhadapLaporan Keuangan (Studi Kasusu Pada PT. Appipa Indonesia. Measurement, Vol.12 No.2 : 180-191 Desember 2018 PISSN 2252-5394.

Sefiana, Eka. 2009. Pengaruh Penerapan Corporate Governance Terhadap Manajemen Laba Pada Perusahaan Manufaktur Yang Go Public di BEI. Jurnal Riset AkuntansiFakultas EkonomiUniversitas Gunadarma, No. 2 Vol IX.

Stice, Earl K, James D Stice dan Fred Skousen, 2009 Akuntansi Keuangan Menengah, Edisi 16, Buku 2. Edisi Bahasa Indonesia. Terjemah Oleh Ali Akbar. PT. Salemba Empat: Jakarta.

Sugiyono. 2012. Metode Penelitian Kuantitatif kualitatif $R \& D$. Bandung: Alfabeta

Sugiyono. 2013. Metode Penelitian Kuantitatif kualitatif $R \& D$. Bandung: Alfabeta

Sukirno, Sadono. 2014. Pengantar Teori Makro Ekonomi. Ed-2. Jakarta: PT Raja Grafindo Persada.

Warsono, Sony dkk, 2009, Corporate Governance Concept and Model, Yogyakarta: Center Of Good Corporate Governance. 